\title{
Autonomy of migration despite of its securitisation? Facing the terms and conditions of
}

\section{biometric rebordering}

\section{Stephan Scheel}

The Open University, Milton Keynes, United Kingdom

\begin{abstract}
This article reconsiders the concept of autonomy of migration (CAM) in the context of technologically ever more sophisticated border regimes by focusing on the case of biometric rebordering. As its name suggests, the CAM's core thesis proposes that migratory movements yield moments of autonomy in regards to any attempt to control and regulate them. Yet, the CAM has been repeatedly accused of being based on and contributing to a romanticisation of migration. After outlining two advantages the CAM offers for the analysis of biometric border regimes, I demonstrate that processes of biometric rebordering increase the warranty of the two allegations, which feed this major critique. Drawing on examples relating to the Visa Information System (VIS), I show, moreover, that processes of biometric rebordering alter the practical terms and material conditions for moments of autonomy of migration to such an extent that it becomes necessary to rethink not only some of the CAM's central features, but the notion of autonomy itself. In the final section I therefore point out some directions to develop the CAM as an approach, which is better equipped to investigate today's struggles of migration without being prone to the critique of implicating a romanticisation of migration.
\end{abstract}

\section{Keywords}

Autonomy of migration, biometric rebordering, securitisation, dispositif, situated knowledge

[...] there is an autonomy of emigration adverse to the politics of states and this accounts for emigration as well as immigration. [...] Though myriads of experts and officials in the administrative bodies of state institutions and international organisations are preoccupied with emigration, they have no clue about this independence or autonomy of migration flows. [...] One can counteract emigration with repressive means, 'advance' the return of immigrants, but one can not open or block the flows from one's point of view and programming. ${ }^{1}$

Since Yann Moulier Boutang postulated the hypothesis of an autonomy of migration, scholars from around the world have tried - often independently from one another - to develop it into a 'heuristic model' ${ }^{2}$ to investigate and intervene in the struggles of migration. ${ }^{3}$ This article

\footnotetext{
${ }^{1}$ Yann Moulier Boutang, "Interview," in Materialien für einen neuen Antiimperialismus Nr. 5, ed. N.N. (Berlin Göttingen Schwarze Risse/ Rote Straße, 1993), 38. Emphasis in original.

2 "Europa, Autonomie der Migration, Biopolitik," in Empire und die biopolitische Wende. Die Internationale Diskussion im Anschluss an Negri und Hardt, ed. Marianne Pieper, et al. (Frankfurt am Main: Campus, 2007), 167.

${ }^{3}$ Important contributions to this debate include: De l'esclavage au salariat. Économie historique du salariat bridé (Paris: Presse Universitaires de France, 1998); Sandro Mezzadra, Derecho de fuga: Migraciones,
} 
understands itself as a contribution to this ongoing undertaking. It argues that the material terms and practical conditions for the emergence of possible moments of autonomy of migration have changed significantly due to the increased technologisation of border regimes. Yet, the existing literature on the concept of autonomy of migration (CAM) has so far not sufficiently acknowledged the impact of the technologisation of border controls on the possibilities of migrants to appropriate what contemporary border and migration regimes seek to deny them, namely: mobility and rights. What has hindered the advocates of the CAM so far to take the technologisation of border controls and its effects on migrants' room for manoeuvre seriously is the misreading of the interrelated securitisation of migration as a mere means for the economic exploitation of migrant labour. ${ }^{4}$ This is why the CAM's core hypothesis has been largely articulated as an unqualified generalisation to date: moments of autonomy seem to emerge and operate within any border and migration regime irrespective of its legal, practical and technological composition.

In this article I therefore reconsider the CAM in face of the ongoing technologisation of border controls by focusing on the challenges posed by biometric rebordering. My analysis is driven by the following question: In which directions has the CAM to be refined to better account for the impact of the technologisation of border control on the emergence of possible moments of autonomy of migration?

To answer this question, I first outline six core features of the CAM. This enables me to bring out two conceptual advantages the CAM yields for the investigation and critique of biometric border regimes. In the second and third section I reconsider the two allegations that fuel the major critique, according to which the CAM is based on, but also contributes to a

ciudadanía y globalización (Madrid: Traficantes de Suenos, 2005); Sandro Mezzadra and Brett Neilson, Border as Method, Or, the Multiplication of Labor (Durham: Duke University Press, 2013); Dimitris Papadopoulos, Niamh Stephenson, and Vassilis Tsianos, Escaperoutes. Control and Subversion in the Twenty-first Century (London: Pluto Press, 2008); Transit Migration Forschungsgruppe, Turbulente Ränder. Neue Perspektiven auf Migration an den Grenzen Europas (Bielefeld: transcript, 2007). Finally, it is worth mentioning that the CAM has been popularised by Negri and Hardt, albeit not in an unproblematic way: Michael Hardt and Antonio Negri, Empire (Cambridge, MA \& London Harvard University Press, 2000), Book. 212-14.

${ }^{4}$ While it is hardly disputed that migration has been securitised in the course of the Europeanisation of migration policy, it is still contested how securitisation should be conceptualised. Benjamin Muller, "Risking it all at the Biometric Border: Mobility, Limits, and the Persistence of Securitisation," Geopolitics 16, no. 1 (2011). Thierry Balzacq has introduced a useful distinction between 'philosophical' and 'sociological' approaches. The philosophical variant refers to the definition of securitisation as a performative speech act by political elites, as put forward in the pioneering work of the Copenhagen school. Thierry Balzacq, Securitization Theory: How Security Problems Emerge and Dissolve (London: Routlege, 2010). Following the sociological reading, this article understands securitisation as a technology of government in the Foucaultian sense. Didier Bigo, "Security and Immigration: Toward a Critique of the Governmentality of Unease," Alternatives: Global, Local, Political 27, no. special issue February 2002 (2002); Jef Huysmans, The politics of insecurity : fear, migration and asylum in the EU (London: Routledge, 2006). As such, securitising processes involve multiple actors and dispersed security practices, which are increasingly mediated by identification, information and surveillance technologies. "What's in an act? On security speech acts and little security nothings," Security Dialogue 42, no. 4-5 (2011). 
romanticisation of migration. It becomes more urgent to address these criticisms, as their warranty increases in the context of biometric rebordering. In the final section I therefore point out some directions for re-thinking the CAM in order to develop it as an approach that is better equipped to investigate and intervene in today's struggles of migration within and against technologically ever more sophisticated border regimes and which is no longer prone to the critique of contributing to a romanticisation of migration.

What makes this undertaking necessary is the "technological imperative" ${ }^{, 5}$ driving processes of rebordering in Europe and around the globe. In the context of Europe, the gradual build-up of the surveillance system SIVE along Spanish coasts since 1999 offers an illuminating example. It comprises a network of mobile infrared cameras and high resolution radars, granting patrol boats of the Guardia Civil a response time of up to three hours for intercepting boats with undocumented migrants before their expected arrival on Spanish shores. ${ }^{6}$ So far the CAM's proponents have argued that neither the implementation of ever more restrictive migration policies nor the introduction of technologically ever more sophisticated border controls could inhibit migration, but only downgrade the conditions, under which it occurs. ${ }^{7}$ Indeed, one can trace how the gradual build-up of SIVE implicated a geographical shift to longer and more dangerous migration routes to areas, where it had not yet been installed. ${ }^{8}$ But what happens if an avoidance of technologically highly sophisticated border controls is no longer possible, because they have become generalised? This is by no means a hypothetical question. In the EUROSUR project the European Union (EU) seeks to integrate existing national systems like SIVE into a 'system of the systems' covering its entire maritime border. It also seeks to bring existing surveillance and interception mechanisms to perfection through improved sensors, satellites and unmanned vehicles. ${ }^{9}$

Moreover, EUROSUR is just one expression of the endorsement of technology as a cornerstone of ongoing processes of rebordering in Europe. ${ }^{10}$ It is complemented by proposals

\footnotetext{
5 Gary Chapman, "Shaping Technology for the 'Good Life': The Technological Imperative versus the Social Imperative," in Technology and Society: Building our Sociotechnical Future, ed. Deborah C. Johnson and Jameson M. Wetmore (Cambridge: The MIT Press, 2009).

6 Jørgen Carling, "Migration Control and Migrant Fatalities at the Spanish-African Borders," International Migration Review 41, no. 2 (2007).

${ }^{7}$ Papadopoulos, Stephenson, and Tsianos, Escaperoutes. Control and Subversion in the Twenty-first Century; Rutvica Andrijasevic, "From Exemption to Excess: Detention and Deportations Across the Mediterranean Space," in The Deportation Regime: Sovereignity, Space and the Freedom of Movement, ed. Nichoals De Genova and Nathalie Preutz (Durham \& London: Duke University Press, 2010).

${ }^{8}$ Jørgen Carling, "Unauthorized Migration from Africa to Spain," International Migration 45, no. 4 (2007).

9 Anthony Amicelle et al., "Catalogue of Security and Border Technologies at Use in Europe Today," (Oslo: International Peace Research Institute, 2009), 25-29.

10 Julien Jeandesboz, "Beyond the Tartar Steppe: EUROSUR and the Ethics of European Border Control Practices," in A Threat Against Europe? Security, Migration and Integration, ed. Peter Burgess and S. Gutwirth (Brussels: VUB Press, 2011).
} 
for an entry-exit-system using biometric technologies to record the arrival and departure dates of travellers, who are not EU citizens, or a 'registered traveller programme' permitting participants to enter through automated gates under the condition that they submit themselves to a screening procedure prior to their departure. ${ }^{11}$ While these examples are still projects in the making, the EU has already build-up an impressive architecture of biometric databases, including the EURODAC system for asylum seekers and unauthorised border crossers, the Visa Information System (VIS) for all third country nationals applying for a Schengen visa and, finally, the Schengen Information System (SIS) that registers, among others, migrants who are deported after being apprehended inside the Schengen area. ${ }^{12}$ In this article I illustrate my general claims concerning the impact of the technologisation of border controls on the practical terms and material conditions for the possible emergence of moments of autonomy of migration through examples relating to the VIS.

\section{Politicising the technologisation of border regimes with the CAM: beyond the control bias}

It is important to note that the CAM has always been conceived by its proponents as a political intervention in both migration policy discourse and the politics of the antiracist movement. This brings me to the first of the CAM's six central features that I will outline in this section. First, and in contrast to some of the most influential migration theories, the CAM stresses the subjective and social dimensions of migration in order to critique any conception of migration as a dependent variable of 'objective' factors like poverty or wage differentials, as suggested by neoclassical migration theories, or the destruction of subsistence economies through the expansion of capitalism in the global South, as suggested by the world-system theory. ${ }^{13}$ Any reduction of migration to structural underlying causes ignores the subjective

\footnotetext{
${ }^{11}$ Ben Hayes and Mathias Vermeulen, "Borderline. The EU's New Border Surveillance Initiatives " (Berlin: Heinrich-Böll-Stiftung, 2012).

${ }^{12}$ EURODAC stores the fingerprints of apprehended border crossers and asylum seekers in order to facilitate the implementation of the Dublin II regulation, which stipulates that asylum seekers have to lodge their application in the member state through which they have entered the EU. Yet, EURODAC is also increasingly used for the re-identification of irregular migrants, thereby resembling a prime example for 'function creep' i.e. the usage of databases for purposes beyond the initially stated objectives. The VIS will soon be the largest biometric database in the world as it stores the fingerprints and facial images of the up to 20 million people, who annually apply for a Schengen visa, for a period of five years. Dennis Broeders, "The New Digital Borders of Europe: EU Databases and the Surveillance of Irregular Migrants," International Sociology 22, no. 1 (2007). The SIS is the oldest EU database for migration control purposes. It's second generation will also store the fingerprints of deported migrants and other 'undesirable' persons, but its start of operation has been repeatedly postponed. Evelien Brouwer, Digital Borders and Real Rights: Effective remedies for third-country nationals in the Schengen Information System (Leiden: Martinus Nijhoff Publishers, 2008). Hayes and Vermeulen, "Borderline. The EU's New Border Surveillance Initiatives " 32.

13 Yann Moulier Boutang, "Nicht länger Reservearmee. Thesen zur Autonomie der Migration und zum notwendigen Ende des Regimes der Arbeitsmigration," Subtropen. Kritik und Versprechen, no. April 2002
} 
desires and projects migrants pursue with their migrations, thereby eliminating the political moments migratory movements comprise. The CAM's advocates attribute the autonomy of migration, by contrast, to the uncontrollable plenitude of thousands of independent decisions, which are taken by migrants for a wide variety of different reasons on a daily basis. It is this subjective dimension of migration that Sandro Mezzadra seeks to underscore with the notion of escape ${ }^{14}$ It produces a surplus of sociability, which exceeds the capacities of any border regime to regulate migratory movements entirely. ${ }^{15}$

Therefore, migration is conceived, second, as a 'dynamic force' with the potential to instigate social transformation processes. ${ }^{16}$ In brief, the subjective movement of living labour constitutes a driving force in the evolution of capital accumulation. ${ }^{17}$ The institution of wage labour as a crucial moment in the history of capitalism was, for instance, prompted by the escape of slaves from the plantation economies. ${ }^{18}$ Likewise, contemporary migrations are structurally in excess of the equilibriums of (national) labour markets and codified forms of citizenship, that practices of rebordering try to maintain, thereby forcing these (and other) institutions into a process of permanent reorganisation and adaptation. ${ }^{19}$ This conception of migration as a constituent force leads the CAM's advocates to read 'migration in itself as an articulation of political and social struggles. ${ }^{20}$

From this understanding of migration follows, third, that the CAM's advocates refute any victimisation of migrants. For any victimising discourse erases migrants capacity to subvert border controls, which in turn enables to ignore the fact, that 'migrants have a will of their own, one that lies outside of the hands of those who wish to [help or] control them. ${ }^{21}$ Accordingly, the representation of migrants as needy victims enables paternalistic proxy

(2002). For a good overview of the most influential migration theories see, for instance: Douglas Massey et al., "Theories of International Migration: A Review and Appraisal," Population and Development Review 19, no. 3 (1993).

${ }^{14}$ Mezzadra, Derecho de fuga: Migraciones, ciudadanía y globalización: 45-46.

${ }^{15}$ Moulier Boutang, "Nicht länger Reservearmee. Thesen zur Autonomie der Migration und zum notwendigen Ende des Regimes der Arbeitsmigration."; Sandro Mezzadra, "The gaze of autonomy: capitalism, migration and social struggles," in The Contested Politics of Mobility Borderzones and Irregularity ed. Vicky Squire (London: Routledge, 2011); Papadopoulos, Stephenson, and Tsianos, Escaperoutes. Control and Subversion in the Twenty-first Century: 77-78.

${ }^{16}$ Vassilis Tsianos and Serhat Karakayali, "Transnational Migration and the Emergence of the European Border Regime: An Ethnographic Analysis," European Journal of Social Theory 13, no. 3 (2010): 386.

${ }^{17}$ Moulier Boutang, De l'esclavage au salariat. Économie historique du salariat bridé: 16; Mezzadra, Derecho de fuga: Migraciones, ciudadanía y globalización: 45.

${ }^{18}$ Moulier Boutang, De l'esclavage au salariat. Économie historique du salariat bridé.

${ }_{19}$ Manuela Bojadžijev and Serhat Karakayali, "Autonomie der Migration. 10 Thesen zu einer Methode," in Turbulente Ränder. Neue Perspektiven auf Migration an den Grenzen Europas, ed. Transit Migration (Bielefeld: transcript, 2007); Mezzadra, "The gaze of autonomy: capitalism, migration and social struggles."

${ }^{20}$ Serhat Karakayali and Vassilis Tsianos, "Mapping the Order of New Migration. Undokumentierte Arbeit und die Autonomie der Migration," Peripherie 25, no. $97 / 98$ (2005): 51. Translation by the author.

${ }^{21}$ Nandita Sharma, "Escape artists: Migrants and the polites of naming," Subjectivtity, no. 29 (2009): 469. 
policies as pursued by humanitarian organisations like the UNHCR, but also by some groups of the antiracist movement. ${ }^{22}$ Or, even worse, it is exploited by advocates of migration control as a justification for the build-up and perfection of border controls. The costly EUROSUR project cited in the introduction offers an illuminating example for this justification strategy: 'The tragic death toll resulting from this kind of illegal immigration [in boats across the Mediterranean] is unacceptable and must therefore be significantly reduced. The capacity to detect small boats in the open sea must be enhanced, contributing to greater chances of search and rescue and thereby saving more lives at sea. 23

But the reading of migration as a constituent force also entails important consequences for the conception and analysis of borders. For the CAM's proponents suggest, fourth, that migratory movements temporarily precede the attempts to control, regulate and valorise them. ${ }^{24}$ From this follows, fifths, that the analytical starting point of the CAM relies on a reversal of the state-centred perspective, which is shared by the majority of migration studies, as Stephen Castles has rightly criticised. ${ }^{25}$ It is precisely this reversal of the state and control perspective, in which the CAM's theoretical legacy of autonomist Marxism comes to the fore. In contrast to the assumption of orthodox Marxism, whereupon the course of history is determined by economic laws inherent to the capitalist mode of production, autonomist Marxists regard the social and political struggles of the working class as the 'motor of history' and therefore make them the central reference point for any empirical investigation and theoretical consideration. ${ }^{26}$ In this vein, Moulier Boutang calls upon migration scholars to

\footnotetext{
${ }^{22}$ A. Mitropoulos, "Autonomy, Recognition, Movement," in Constituent Imagination. Militant Investigations, Collective Theorization, ed. S. Shukaitis, D. Graeber, and E. Biddle (Oakland: AK Press, 2007), 130-31; Papadopoulos, Stephenson, and Tsianos, Escaperoutes. Control and Subversion in the Twenty-first Century: 203.

${ }^{23}$ European Commission, "Commission staff working document - Examining the creation of a European border surveillance system (EUROSUR) - Impact assessment', SEC(2008) 152 final," (Brussels2008), 4. For a critique of this supposedly humanitarian justification: Jeandesboz, "Beyond the Tartar Steppe: EUROSUR and the Ethics of European Border Control Practices." But the justification for the build-up or intensification of border controls through a victimisation of certain groups of migrants is also present in the anti-trafficking discourse of the IOM and certain NGO's: Rutvica Andrijasevic, "Beuatiful dead bodies: Gender, migration and representation in antitrafficking campaigns," Feminist Review, no. 86 (2007); Rutvica Andrijašević, Migration, Agency and Citizenship in Sex Trafficking (Basingstoke: Palgrave, 2010). The same justification mechanism is also at work in the refugee-protection-discourse of the UNHCR: Stephan Scheel and Philipp Ratfisch, "Refugee Protection Meets 'Migration Management': the UNHCR as a Global Police of Populations," Journal of Ethnic and Migration Studies, special issue on 'migration management and its discontents' (forthcoming).

${ }^{24}$ Moulier Boutang, "Europa, Autonomie der Migration, Biopolitik," 169-70; Papadopoulos, Stephenson, and Tsianos, Escaperoutes. Control and Subversion in the Twenty-first Century: 199. Sandro Mezzadra and Brett Neilson, "Né qui, né altrove - migration, detention, desertion: a dialogue," Borderlands e-journal 2, no. 1 (2003).

${ }^{25}$ Stephen Castles, "Understanding Global Migration: A Social Transformation Perspective," Journal of Ethnic and Migration Studies 36, no. 10 (2010).

${ }^{26}$ Mario Tronti, "Lenin in England," in Working Class Autonomy and the Crisis, ed. Red Notes (London: Red Notes and CSE, 1979).
} 
assume the mobile perspective of the movement of migration in order to ask, how migrants try to overcome and subvert border controls. ${ }^{27}$

Consequently and finally, the advocates of the CAM criticise any representation of borders as impenetrable walls, as suggested by the influential metaphor of Fortress Europe, which dominated the slogans and campaigns of the antiracist movement in Europe throughout the 1990s. In brief, they criticise the latter for not capturing migrants' capacity to render borders porous and, hence, the moments of autonomy of migration. Moreover, they maintain that the image of the fortress would not account for the productivity of border controls. Instead of conceiving border controls as repressive means aiming at the exclusion of migrants, the CAM's proponents suggest that today's border regimes follow a rationale of 'differential inclusion. ${ }^{28}$ Border controls create the conditions for migrants' economic exploitation through their gradual, but systematic disenfranchisement. ${ }^{29}$ Therefore, the CAM's advocates understand 'illegality' not as a legal (non-)status, but as an actively produced, albeit contested condition that aims at disciplining migrants to a docile, flexible and exploitable workforce by rendering them 'deportable'. ${ }^{30}$ They emphasise, however, that it is migrants in the first place, who render borders porous. Accordingly, it is migrants' practices that recode the devices of border control into mechanisms, that still enable mobility and labour, but only under the precarious conditions of 'illegality'. ${ }^{31}$ Consequently, the CAM's proponents conceptualise borders not as the impenetrable walls of an imagined fortress, but as dynamic sites of contestation and negotiation, where migrants' practices and tactics encounter the strategies and devices of control, entering a 'relationship of reciprocal determination., 32

To my mind, it is precisely the strategic-analytical prioritisation of migrants' practices and the related conception of borders as sites of contestation and conflict, which constitute two important advantages the CAM contributes to the analysis of biometric borders. These conceptual and analytical advantages entail, in turn, crucial political implications. It should be

\footnotetext{
${ }^{27}$ Moulier Boutang, "Europa, Autonomie der Migration, Biopolitik," 170.

${ }^{28}$ Bojadžijev and Karakayali, "Autonomie der Migration. 10 Thesen zu einer Methode."; Sandro Mezzadra and Brett Neilson, "Borderscapes of Differential Inclusion: Subjectivity and Struggles on the Threshold of Justice's Excess'," in Other Spheres of Justice, ed. Étienne Balibar, Sandro Mezzadra, and Ranabir Samaddar (Philadelphia: Temple University Press, 2012), 189-94.

29 "Border as Method," (2008), http://translate.eipcp.net/transversal/0608/mezzadraneilson/en.

${ }^{30}$ Mezzadra, "The gaze of autonomy: capitalism, migration and social struggles." The concept of 'deportability' asserts in regards to the function of deportations that not their actual execution is decisive, but that already the fact of their possible execution establishes a condition of deportability, which disciplines irregular migrants to a flexible, exploitable workforce. Nicholas De Genova, "Migrant "Illegality" and Deportability in Everyday Life," Annual Review of Anthropology 31, no. 3 (2002).

${ }^{31}$ Karakayali and Tsianos, "Mapping the Order of New Migration. Undokumentierte Arbeit und die Autonomie der Migration," 50.

32 Bojadžijev and Karakayali, "Autonomie der Migration. 10 Thesen zu einer Methode," 204; author's translation.
} 
noted that they concern the investigation of technologically ever more sophisticated border regimes in general beyond the case of biometric borders discussed here.

First, the CAM is well equipped to counter the control bias that characterises the existing literature on biometric border controls. The bulk of this literature focuses its analysis on the practices, technologies, installations, devices, statements and agencies that characterise the appearance and make-up of biometric borders in specific contexts, sites or programmes in order to reveal their key features, underlying rationalities and effects. ${ }^{33}$ Those, who are abjectified by being rendered as 'risky' by biometric border controls, conversely, only appear as passive targets of practices of surveillance, control and exclusion. Consequently, their practices and tactics that are geared towards the subversion of biometric border controls remain unexplored. As a result of this neglect, the existing literature overvalues the efficiency of biometric and other border control technologies. Such control biased analyses then tend to represent biometric borders as 'omnipotent control apparatuses' ${ }^{34}$, which are actually capable of facilitating the mobility of 'trusted travellers' by efficiently restricting the mobility of those classified as 'risky'. Biometric borders appear as the promised ultimate technological fix capable to reconcile the two allegedly conflicting 'governmental desires [of] security and mobility' that constitute the 'problem of the border' in the age of globalisation. ${ }^{35}$ In the end, control biased analyses of biometric borders involuntarily confirm and even fuel the claims, which justify and drive the implementation of biometric technologies in the first place. ${ }^{36}$

By making the practices of abjectified migrants the starting and focal point of any investigation of borders the CAM allows for avoiding such control biased analyses. Today's biometric borders no longer appear as mere technological installations perfectly regulating human mobility. They rather emerge as what Vicki Squire calls borderzones: as dispersed

\footnotetext{
${ }^{33}$ See, for instance, the following contributions: Louise Amoore, "Biometric borders: Governing mobilities in the war on terror," Political Geography 25, no. 3 (2006); Ayse Ceyhan, "Technologization of Security: Management of Uncertainty and Risk in the Age of Biometrics " Surveillance \& Society 5, no. 2 (2008); Karine Côté-Boucher, "The Diffuse Border: Intelligence-Sharing, Control and Confinement along Canada's Smart Border," Surveillance \& Society 5, no. 2 (2008); Benjamin Muller, Security, Risk and the Biometric State (Oxon/ New York: Routledge, 2010); Nick Vaughan-Williams, "The UK border security continuum: virtual biopolitics and the simulation of the sovereign ban," Environment and Planning D: Society and Space 28(2010); Dean Wilson and Leanne Weber, "Surveillance, Risk and Preemption on the Australian Border," Surveillance \& Society 5, no. 2 (2008).

${ }^{34}$ Efthimia Panagiotidis and Vassilis Tsianos, "Denaturalizing "Camps": Überwachen und Entschleunigen in der Schengener Ägäis-Zone," in Turbulente Ränder. Neue Perspektiven auf Migration an den Grenzen Europas, ed. Transit Migration Forschungsgruppe (Bielefeld: transcript, 2007).

${ }^{35}$ Mark B Salter, "Passports, Mobility, and Security: How smart can the border be?," International Studies Perspectives 5, no. 1 (2004): 72.

${ }^{36}$ This 'control bias' haunts most of the literature on the technologisation of border controls in general. For examples beyond the case of biometrics see for instance: Brian Martin and Steve Wright, "Looming struggles over technology for border control," Journal of Organisational Transformation and Social Change 3, no. 1 (2006). Sarah Wolff, "Border Management in the Mediterranean: Internal, External and Ethical Challenges," Cambridge Review of International Affairs 21, no. 2 (2008).
} 
sites of intensified political struggles over the selective denial and appropriation of mobility and rights. ${ }^{37}$ The technological details of biometric border controls are no longer catalogued in a meticulous description of supposedly omnipotent control apparatuses. They rather emerge as the terrain of as well as stakes within migrants' struggles over the direct appropriation of mobility and rights. These silent and clandestine, but inherently political struggles manifest themselves in those multiple sites and situations, in which the practices and tactics of abjectified migrants encounter the techniques and devices of control. It is through the empirical investigation of these encounters by means of a multi-sited ethnography that scholars can bring out these multiple struggles, thereby avoiding a static and control biased analysis. ${ }^{38}$ As a result, today's biometric borders would no longer appear as sites of perfect mobility control, ultimately constituting a 'cyber-fortress' in the making. ${ }^{39}$ They would rather emerge as the battleground of dynamic political struggles over the selective denial and direct appropriation of mobility and rights.

It is this conception of biometric borders as sites of political struggles, through which the CAM permits researchers, secondly, to counter the de-politicisation of border controls implicated by their technologisation. Philppe Bonditti has rightly argued that ' $[t]$ he excessive resorting to technology effectively hides the political character of problems that technology is intended to solve. ${ }^{40}$ More precisely, it is the underlying representation of border controls as a mere technical problem that can be 'solved' through the implementation of innovative control technologies, which brings about the de-politicisation of the practices they involve, the effects they produce as well as of the context, in which they take place. ${ }^{41}$ Many authors follow Didier

\footnotetext{
${ }^{37}$ Vicki Squire, "The contested politics of mobility: Politicizing mobility, mobilizing politics," in The Contested Politics of Mobility: Borderzones and Irregularity, ed. Vicki Squire (London: Routledge, 2011).

${ }^{38}$ Sabine Hess, "De-Naturalising Transit Migration. Theory and Methods of an Ethnographic Regime Analysis," Population, Space and Place 18, no. 4 (2012): 430. Since multi-sited research is based on a radical constructivism neither the object of inquiry nor the field of study are regarded as pre-given, but emerge in the research process. As 'the object of the study is thought of as mobile and multiply situated' the endeavor of multisited research lies - in this case - in tracing and tracking migrants' encounters with border controls across and within multiple sites. George Marcus, "Ethnography in/of the World-System: The Emergence of Multi-Sited Geography," Annual Review of Anthropology 24, no. 1 (1995): 102, 97.

${ }^{39}$ Elspeth Guild, Sergio Carrera, and Florian Geyer, "The Commission's New Border Package: Does it take us one step closer to a 'cyber-fortress Europe'? ," in CEPS Policy Brief No. 154, CEPS Policy Brief No. 154 (Brussels: Centre for European Policy Studies, 2008).

${ }^{40}$ Philippe Bonditti, "From Territorial Space to Networks: A Foucaldian Approach to the Implementation of Biometry," Alternatives: Global, Local, Political 29, no. 4 (2004): 466.

${ }^{41}$ Benjamin Muller has, for instance, criticised the representation of biometric technologies as a side-effect free solution to balance the alleged tension between security and freedom of movement. The usage of biometric technologies in conjunction with the related risk management approach implicates, however, that unrestricted mobility is only available to those, who make themselves completely transparent to border control authorities, as security is equated with visibility. Muller, Security, Risk and the Biometric State: 95. Along similar lines Didier Bigo argues that the technologisation of border controls ultimately translates freedom of movement into ever more pervasive dataveillance. Didier Bigo, "Freedom and speed in enlarged borderzones," in The Contested Politics of Mobility: Borderzones and Irregularity, ed. Vicki Squire (Oxon and New York: Routledge, 2011).
} 
Bigo's observation, whereupon technologies like biometrics and related techniques like 'risk profiling' are performative as they permit security professionals to monopolise the authority to define what or who constitutes a 'risk' as well as to decide how and by what means to neutralise them. ${ }^{42}$ These highly political questions are reduced to mere technical problems, which can be 'solved' by certain 'experts', who are endued with a secret 'insider knowledge' due to their access to information and surveillance technologies. These technologies in turn accord the 'insider knowledge' claimed by security professionals an aura of objectivity and scientific certainty, making it difficult, if not impossible, for others to contest their accounts, decisions and practices. ${ }^{43}$ The successful representation of border controls as purely technical, apolitical issues only certain experts can have a say on due to their proclaimed 'professional expertise', in turn, invests the technologisation of border controls with a self-perpetuating dynamic. ${ }^{44}$ The failure of technologies to deliver the promised perfect security translates into a call for the implementation of more and better technologies by security professionals.

In this context, the CAM allows critical scholars to precipitate a re-politicisation of border controls by depicting them as the terrain of political struggles, which can not be solved through the implementation of technologies, because they concern the access of abjectified migrants to mobility and rights. These struggles and contestations are initiated by migrants' attempts to appropriate what border controls seek to deprive them of: mobility and rights. Consequently, migrants' practices of direct appropriation and the struggles they instigate are inherently political in themselves. For it is these practices of abjectified migrants, which render today's biometric borders, as well as the legally codified forms of citizenship and the socioeconomic status quo they try to maintain, as objects of contestation and dissent. ${ }^{45}$ Attempts to counter the de-politicisation of border controls afford, therefore, that scholars follow the CAM's suggestion to conceive migrants not as passive objects of control, but as crucial actors in the make-up of the multiple sites and situations at today's biometric borders. It is then an investigation of migrants' practices of direct contestation and appropriation, which has to be the starting and focal point of an analysis of biometric borders that aims at their re-politicisation.

\footnotetext{
Moreover, numerous scholars in critical security studies have criticised that the discriminatory effects of border controls become concealed, but nevertheless persist and even intensify in the context of biometric rebordering. I discuss this point in detail in the next section.

42 "Security and Immigration: Toward a Critique of the Governmentality of Unease."

43 Louise Amoore and Marieke De Goede, "Introduction: Governing by Risk in the War on Terror," in Risk and the War on Terror, ed. Louise Amoore and Marieke De Goede (London: Routledge, 2008).

${ }^{44}$ Muller, Security, Risk and the Biometric State: 46-47.

45 Andrew Barry, Political Machines: Governing a Technological Society (London \& New York: The Athlone Press, 2001). 6.
} 


\section{The CAM revisited I: autonomy or romanticisation of migration?}

The CAM is, however, not without problems itself. As I have noted in the introduction, the CAM, and most importantly, its generalised attribution of moments of autonomy to any migratory movement are repeatedly criticised for being based on as well as contributing to a romanticisation of migration. This major critique is fuelled by two interrelated allegations. Considering each of these two allegations in this section and the next, I demonstrate that their warranty increases in the context of biometric rebordering.

First, the CAM is accused of not sufficiently considering the diversity of conditions, under which migration occurs. ${ }^{46}$ According to critics, this diversity of conditions arises from both migrants' unequal access to resources and the varying degrees of discrimination they experience due to the prevalence of sexist and racist discourses throughout the migration process. Martina Benz and Helen Schwenken attribute this neglect to the notion of autonomy itself that would reduce the diverse social conditions surrounding migration to a juxtaposition of state versus migrants. ${ }^{47}$ The CAM would frame migrants as a single autonomous collective subject, while ignoring their different subject positions and the specific constraints and privileges these subject positions entail. Following the concept of triple oppression, they insist that the combined, but individually varying effects of racism, sexism and capitalism have to be considered in order to assess in how far particular migrations yield emancipatory results or rather contribute to the re-articulation of relations of domination and exploitation.

Members of Transit Migration have in turn refuted this criticism as a misinterpretation of the CAM, which would emphasise the autonomy of migratory movements, but not of individual subjects. ${ }^{48}$ They argue that Benz and Schwenken's critique reflects a 'naïve empiricism of the subject', which confuses the difference between a situated analysis of the border regime from the perspective of migration with a purely empirical investigation of migrants' subjectivities. They maintain, by contrast, that such a situated analysis can only be attained by using border-transgressing biographies and the practices of migration as empirical

\footnotetext{
46 Sunny Omwenyeke, "Autonomy of Migration: Where We Stand in the Debate," (2004), http://thecaravan.org/node/25; Gregor Samsa, "Autonome Hintereingänge in die Festung Europa?! Antirassistsiche Perspektiven in Sachen G8-2007," AK - analyse \& kritik (Zeitschrift für linke Debatte und Praxis) 2006.

${ }^{47}$ Martina Benz and Helen Schwenken, "Jenseits von Autonomie und Kontrolle: Migration als eigensinnige Praxis," PROKLA - Zeitschrift für kritische Sozialwissenschaften 35, no. 140 (2005).

${ }^{48}$ Manuela Bojadžijev, Serhat Karakayali, and Vassilis Tsianos, "Das Rätsel der Ankunft. Von Lagern und Gespenstern. Arbeit und Migration," Kurswechsel - Zeitschrift für gesellschafts-, wirtschafts- und umweltpolitische Alternativen, no. 2/2003 (2003): 48.
} 
samples, but not by studying the 'empirical' practices of migrants. ${ }^{49}$ Through the distinction between the 'practices of migration' and the 'practices of migrants' the members of Transit Migration intend to emphasise, that the moments of autonomy of migration can only be observed in the historical course of a multiplicity of migratory movements, but not by referring to the success or failure of individual migration projects.

Yet, this emphasis on 'practices of migration' is prone to subsuming the varying lived experiences of concrete subjects under the subjectless and equalising abstraction of migration. Along these lines Nandita Sharma has convincingly criticised the CAM for subsuming the 'hundreds of millions of people who migrate' under the totalising and therefore empty subject position of 'the migrants'. She regards this move as 'a form of symbolic violence', which enables the CAM's proponents to ignore 'migrants' classed, racialized, gendered, sexualized, territorialized bodies' and 'the meanings they themselves give to their experiences. ${ }^{, 50}$ What is needed in light of this critique is then an acknowledgement of the crucial insight of feminist migration research, whereupon mobility is always embodied and relational, and that the lived experiences of migrants are therefore quite diverse. ${ }^{51}$

This diversity arises, in fact, from both migrants' unequal access to economic, social and cultural resources and their differential treatment by border regimes according to their respective subject positions in terms of class, 'race', gender and other sociopolitical relations. Critical scholars have shown, for instance, that informal, albeit institutionalised rules and 'suspect typologies' for migration controls 'lead inevitably to unequal probabilities [for migrants] of being apprehended by the police. ${ }^{52}$ Others have demonstrated that 'the application of immigration law is both sexist and racist' despite of the public insistence on formal equality. ${ }^{53}$ To my mind, this informal, but nevertheless institutionalised unequal treatment of migrants is well captured by the CAM's concept of differential inclusion. It stresses that it is the very function of border regimes to create differences between migrants

\footnotetext{
${ }^{49}$ Sabine Hess and Vassilis Tsianos, "Ethnographische Grenzregimeanalyse. Eine Methodologie der Autonomie der Migration," in Grenzregime: Diskurse, Praktiken, Institutionen in Europa, ed. Sabine Hess and Bernd Kasparek (Berlin: Assoziation A, 2010), 243-44.

${ }^{50}$ Sharma, "Escape artists: Migrants and the politcs of naming," 474.

51 Jennifer Hyndman, "The (Geo)politics of Mobility " in Mapping Women, Making Politics: Feminist Perspectives on Political Geography, ed. Lynn A. Staeheli, Eleanore Kofman, and Lynda Peake (New York: Routledge, 2004), 174; Kim Rygiel, "Governing borderzones of mobility through e-borders: the politics of embodied mobility," in The Contested Poitics of Mobility: Borderzones and irregularity, ed. Vicky Squire (London \& New York: Routledge, 2011), 144..

${ }^{52}$ Godfried Engbergsen and Joanne van der Leun, "Illegality and Criminality: The Differential Opportunity Structure of Undocumented Immigrants," in The New Migration in Europe: Social Constructions and Social Realities, ed. Khalid Koser and Helma Lutz (Basingstoke: MacMillan, 1998), 208-09.

${ }^{53}$ A. Phizacklea, "Migration and Globalization: A Feminist Perspective," in The New Migration in Europe: Social Constructions and Social Realities, ed. Khalid Koser and Helma Lutz ( Basingstoke: MacMillan, 1998), 30 .
} 
through their differential treatment and gradual disenfranchisement. But the existing CAMliterature has not sufficiently considered so far, how this active fabrication of differences is dependent on and (re)productive of racist and sexist practices and economic inequalities. ${ }^{54}$

I would like to argue for a situated re-reading of the notion of autonomy that accounts for both the diversity of migrants' experiences and their varying possibilities to realise their migration projects due to their unequal access to resources in order to highlight the resulting multiplicity of their practices. Instead of leading to "naïve empiricism of the subject ${ }^{55}$ such an approach would allow, first, for developing the concept of differential inclusion further. Secondly, it would underline that experience is always embodied and that it is [therefore] nonsense to speak of a singular migrant subjectivity [...because] there are [...] a myriad of ways to be migrants, which are shaped by lines of class, gender and "race"., 56 Yann Moulier Boutang points towards a situated reading of the notion of autonomy when he argues that:

Colonial as well as postcolonial situation, caste, 'race', gender, [and] ethnicity need to be considered conjointly. The significance of these categories has been acknowledged by now, and each of them has generated a new knowledge: Postcolonial and subaltern studies, minority studies, feminisms all have enriched the notion of autonomy with their respective perspective and invested it with an appropriate complexity. Autonomy is the opposite of heteronomy: not to be dependent, free of effects of domination. Only a situated knowledge (Donna Haraway) can be effectively independent, and correspondingly, one has to protect oneself from the effect of domination, that lurks beneath 'objective' thinking. ${ }^{57}$

Moulier Boutang's acknowledgment of the complexity of the notion of autonomy recognises the diversity of its conditions and the varying degrees of its possible realisation. Yet, none of the CAM's advocates has so far pursued the implicit call to develop a more nuanced reading of autonomy, which is no longer prone to subsume and erase migrants' varying experiences under a subjectless abstraction like migration. ${ }^{58}$

But the need to re-think the CAM in way, which underscores the situatedness and the resulting diversity of migrants' embodied experiences, becomes even more acute in context of

\footnotetext{
${ }^{54}$ Ginette Vertraete, "Technological Frontiers and the Politics of Mobility in the European Union," in Uprootings/Regroundings: Questions of Home and Migration, ed. Sarah Ahmed, et al. (Oxford \& New York: Berg, 2003), 231.

${ }^{55}$ Hess and Tsianos, "Ethnographische Grenzregimeanalyse. Eine Methodologie der Autonomie der Migration," 243-44.

${ }^{56}$ Mezzadra, "The gaze of autonomy: capitalism, migration and social struggles," 134.

${ }^{57}$ Moulier Boutang, "Europa, Autonomie der Migration, Biopolitik," 171. Emphasis adopted from the original, translation by the author.

${ }^{58}$ It should be noted that what Mezzadra seeks to underline with the 'right to escape' is 'the irreducible singularity of the women and men who are the protagonists of migrations [...].' Mezzadra, Derecho de fuga: Migraciones, ciudadanía y globalización: 45, translation by the author. But the implications of this stance for the CAM's core thesis and the underlying understanding of autonomy have remained unexplored so far.
} 
the technologisation of border controls. Critical scholarship on biometric rebordering points out that the differential treatment of migrants according to their positionality in sociopolitical power relations of class, 'race', gender, age and sexual orientation is both intensified and increasingly concealed through the biometrification of border controls.

On the one hand, biometric technologies implicate a differentiation of how the border is experienced. This is far from surprising, if one considers that biometric technologies imply a shift from 'border control to body control. ${ }^{, 59}$ Since biometrics seek to verify the claimed identity of an individual by comparing a representation of one of its biometric features against a digitalised template that has been stored in a database or on an access card like a passport, they allow for a more differentiated and individualised approach towards border controls. ${ }^{60}$ Biometrics permit to replace systematic checks for the targeted control of travellers classified as 'risky' at the physical border in order to accelerate the mobility of 'trusted' travellers. The latter submit themselves to pre-departure checks, thereby trading privacy for speed. ${ }^{61}$ The enrolment in a trusted traveller scheme like NEXUS in Northern America, ${ }^{62}$ 'Project Iris' in the $\mathrm{UK}^{63}$ or the SmartGate system in Australia ${ }^{64}$ allows 'trusted travellers' for an experience of 'borders lite', comprising fast lanes, business lounges and self-policing at automated border check posts. ${ }^{65}$ Travellers who do not want or simply can not participate in these programmes, either because they can not afford them or because 'they come from the wrong background' are, by contrast, automatically deemed 'risky'. ${ }^{66}$ They have to queue repeatedly,

\footnotetext{
${ }^{59}$ Rygiel, "Governing borderzones of mobility through e-borders: the politics of embodied mobility," 148. Muller, Security, Risk and the Biometric State: 12.

${ }^{60}$ Template refers to digital representations of particular biometric characteristics, which are generated by means of algorithms. These templates can be stored, exchanged, searched and matched by computers, which fulfil these tasks much faster and more efficiently than human beings, thereby allowing for the move from human to automated border controls. The crucial innovation lies then not so much in the usage of biometric characteristics for the verification of a person's claimed identity, but in the move from analogous information (photographies of people's faces in passports or a simple ink fingerprint) to digital information. Security, Risk and the Biometric State: 22.

${ }^{61}$ Peter Adey, "Mobilities and Modulations: The Airport as a Difference Machine," in Politics at the Airport, ed. Mark B Salter (Minneapolis: University of Minnesota Press, 2008), 153-56; Bigo, "Freedom and speed in enlarged borderzones." In the end, trusted traveller programmes do not only intensify the controls for those categorised as 'high risk', but also for the 'trusted travellers' themselves as a biometric passport and 'background checks of varying range of intrusiveness' are preconditions for the participation in such a scheme. Benjamin Muller, "Travelers, Borders, Dangers: Locating the Political at the Biometric Border," in Politics at the Airport, ed. Mark B Salter (Minneapolis: University of Minnesota Press, 2008), 136-37. This dimension of trusted traveller programmes is, however, concealed by a 'discourse of convenience', which rearticulates the conventional liberal discourse of rights and responsibilities in a neoliberal fashion as privileges to be invested in. Security, Risk and the Biometric State: 92-93.

${ }^{62}$ Security, Risk and the Biometric State: 89-101; Mathew Sparke, "A neoliberal nexus: Economy, security and the biopoliitcs of citizenship on the border," Political Geography 25, no. 2 (2005).

63 Vaughan-Williams, "The UK border security continuum: virtual biopolitics and the simulation of the sovereign ban."

${ }^{64}$ Wilson and Weber, "Surveillance, Risk and Preemption on the Australian Border."

${ }^{65}$ Amoore, "Biometric borders: Governing mobilities in the war on terror," 343.

${ }^{66}$ Adey, "Mobilities and Modulations: The Airport as a Difference Machine," 156.
} 
either for interrogations at consular posts whilst applying for a visa or for intensified inspections in airports upon arrival. By sorting individuals into fast-moving, low-risk 'kinetic elites' and slow-moving, high-risk 'kinetic underclasses' biometric borders actively produce mobile subjectivities. ${ }^{67}$ The differentiation of how the biometric border is experienced by particular individuals is, however, determined by their respective subject position in terms of class, country of origin, skin colour, gender, age and sexual orientation. ${ }^{68}$ Trusted traveller schemes highlight, moreover, that the alleged privilege to jump the queue, as well as the symbolic capital that comes with it, only come about in relation to the unprivileged in the queue. ${ }^{69}$ What the usage of biometric technologies in voluntary trusted traveller schemes and databases only mandatory for those considered 'high-risk' then brings to the fore is that mobility is, in fact, always embodied and relational.

On the other hand, it is precisely this connection between the differential treatment of mobile individuals and their respective positionality in terms of class, race and gender, which is concealed by biometric border controls technologies. The latter supposedly do not suffer from the prejudices shared by human beings as they verify a person's claimed identity on the basis of features of its biological body independently of any factors, which might be regarded as discriminatory (such as class, 'race', gender or sexuality). ${ }^{70}$ Irma van der Ploeg has succinctly argued, by contrast, that biometrics transform the biological body into a machine readable 'text'. She emphasises that 'the meaning and significance' of this machine readable text is contingent upon 'the context', in which it is produced, and the relations, which are established with other 'texts'. ${ }^{71}$ It is through both the social context, in which biometrics are deployed, and the comparisons, for which the machine readable texts they produce are used, that all forms of discrimination in terms of class, 'race' and gender come into play.

In the context of border controls, biometric technologies are not only used for the maintenance of the political and socioeconomic status quo by regulating the access to and exclusion from mobility, rights and geographical spaces. In addition, they also create new inequalities. The trusted traveller programmes mentioned above illustrate that biometric technologies contribute to the creation of a privileged 'kinetic elite'. Membership to this

\footnotetext{
67 "“Divided We Move": The Dromologics of Airport Security and Surveillance," in Surveillance and Society: Technological Politics and Everyday Life, ed. Torin Monahan (New York Routledge, 2006).

${ }^{68}$ Côté-Boucher, "The Diffuse Border: Intelligence-Sharing, Control and Confinement along Canada's Smart Border." Rygiel, "Governing borderzones of mobility through e-borders: the politics of embodied mobility."

${ }^{69}$ Adey, "Mobilities and Modulations: The Airport as a Difference Machine," 154-55.

${ }^{70}$ Muller, Security, Risk and the Biometric State: 97-98, 120; Rygiel, "Governing borderzones of mobility through e-borders: the politics of embodied mobility."

${ }^{71}$ Irma Van der Ploeg, "Written on the Body: Biometrics and Identity " Computers and Society 29, no. 1 (1999): 46.
} 
exclusive club is only open to those who can afford it and are classified as 'low risk'. The VIS exemplifies, by contrast, that the enrolment into biometric databases becomes mandatory for all those, who are regarded as a security or 'migration risk'. In order to be able to capture and critique these discriminatory effects of biometric borders it becomes necessary to develop the CAM as an approach, which conceives mobility as both embodied and relational. For feminist migration scholars have shown that unrestricted access to mobility of some is connected to the restriction of the access to mobility for others. ${ }^{72}$ But the CAM needs to better account for the diversity of migrants' subject positions and the resulting diversity of their migration experiences and border crossing practices. This is necessary in order to retain the capacity to critique, how technologically 'consolidated identities for some produce marginalised locations for others' within material-semiotic contexts, in which sexist and racist discourse and practices are virulent. ${ }^{73}$ What becomes therefore even more urgent in the context of biometric rebordering is the development of a reading of autonomy that allows for a situated analysis of migrants' embodied and consequently diverse encounters with and experiences of today's biometric borders.

\section{The CAM revisited II: autonomy of migration despite of its securitisation?}

In addition, the CAM has been accused of an unfounded stylisation of migrants to self-reliant heroes of clandestine border crossing. In brief, critics maintain the CAM's proponents would systematically gloss over the repressive and sometimes murderous effects of ever more restrictive border controls, which often resulted in the effective exclusion of migrants. ${ }^{74}$ In this section I argue that it becomes necessary to consider this criticism, because it becomes more warranted in the context of the securitisation of migration and interrelated processes of biometric rebordering. Biometric databases alter the encounters and power relations between migrants and border control authorities to such an extent that it becomes necessary to re-think some of the CAM's core assumptions, including the notion of autonomy itself.

In my opinion, it is the insufficient consideration of the securitisation of migration and its bearing on the rationale and design of contemporary border regimes, which justifies the

\footnotetext{
${ }^{72}$ Hyndman, "The (Geo)politics of Mobility "; Rygiel, "Governing borderzones of mobility through e-borders: the politics of embodied mobility."

73 Donna Haraway, Modest_Witness@Second_Millenium.FemaleMan_Meets_OncoMouse. Feminism and Technoscience (London \& New York: Routledge, 1997). 38. Vertraete, "Technological Frontiers and the Politics of Mobility in the European Union."

${ }^{74}$ Omwenyeke, "Autonomy of Migration: Where We Stand in the Debate"; Samsa, "Autonome Hintereingänge in die Festung Europa?! Antirassistsiche Perspektiven in Sachen G8-2007."
} 
allegation, whereupon the CAM plays down, or even ignores, the repressive and exclusionary effects of border controls. Prominent advocates of the CAM like Sandro Mezzadra have so far only paid lip-service to the fact that migration has been increasingly framed and treated as a security issue since the $1980 \mathrm{~s}^{75}$ While Mezzadra acknowledges that securitising practices are 'leading to a further restriction of their [irregular migrants] spaces and freedom of mobility ${ }^{\text {, }}$ he and other advocates on the CAM insist, nevertheless, that 'the modus operandi of the migration regime [...] revolves around the question of labour. ${ }^{77}$ Following Mezzadra, today's border regimes resemble 'a complex dispositif, which is based both on the valorisation and containment of labour mobility. ${ }^{78}$ In this account, the securitisation of migration emerges as nothing but a strategy for the ultimate economic endeavour to discipline migrants to a docile and exploitable workforce.

I would like argue, by contrast, that the reading of the securitisation of migration as a "modality for the global "irregularisation" of migrant labour" ${ }^{79}$ constitutes an oversimplifying economic reductionism. This economic reductionism misinterprets one of the effects of securitising practices - the facilitation of the exploitation of migrant labour through their illegalisation - as the overall rationale of the securitisation of migration. But the securitisation of migration cannot be subsumed under supposedly higher ranking economic ends, because it involves the invocation of a politics of fear that reduces possible migration policy options to strategies of distancing and neutralising the 'risks' that are associated with human mobility. ${ }^{80}$ Through the politics of fear migrants are constructed as a risk for potential harm, which has to be kept at a spatial and social distance through a plethora of illiberal security practices. ${ }^{81}$ Consequently, the securitisation of migration has, in fact, strong implications for the design, composition and underlying rationale of today's border regimes.

This does, however, not imply that I propose to simply replace the prioritisation of the question of labour in the understanding and analysis of contemporary border regimes with the securitisation of migration. Nor do I suggest that the paradigm of exclusion, which has been

\footnotetext{
75 Bigo, "Security and Immigration: Toward a Critique of the Governmentality of Unease."; Huysmans, The politics of insecurity : fear, migration and asylum in the EU; Muller, "Risking it all at the Biometric Border: Mobility, Limits, and the Persistence of Securitisation."; Rens van Munster, Securitizing Immigration. The Politics of Risk in the EU (Basingstoke: Palgrave, 2009).

${ }^{76}$ Mezzadra, "The gaze of autonomy: capitalism, migration and social struggles," 229.

${ }_{77}$ Bojadžijev, Karakayali, and Tsianos, "Das Rätsel der Ankunft. Von Lagern und Gespenstern. Arbeit und Migration," 48. Translation by the author.

${ }^{78}$ Mezzadra, "The gaze of autonomy: capitalism, migration and social struggles," 227.

${ }^{79}$ Nicholas De Genova, "Alien powers: Deportable labour and the spectacle of security," in The Contested Politics of Mobility: Borderzones and Irregularity, ed. Vicki Squire (London/ New York: Routledge, 2011$), 94$.

${ }^{80}$ Huysmans, The politics of insecurity : fear, migration and asylum in the EU: 52-55.

${ }^{81}$ Bigo, "Security and Immigration: Toward a Critique of the Governmentality of Unease."; Huysmans, The politics of insecurity : fear, migration and asylum in the EU: 54-57.
} 
so vividly criticised by the CAM's advocates, has become the dominant rationale of today's border regimes due to the securitisation of migration. Numerous CSS-scholars have repeatedly shown that the security framing of migration does not implicate a repression of human mobility through a fortification of borders. ${ }^{82}$ Following Foucault, they have argued that security is not opposed to freedom of movement, but rather emerges as its 'correlative'. ${ }^{83}$ They emphasise that the speed and comfort of unrestricted mobility for the normalised majority of travellers hinges on the intensified control and possible banishment of those classified as 'risky'. This particular mode of exclusion does, however, not work through the interdiction or prevention of mobility, but rather produces a mobile satellite population, which is kept at a social and spatial distance, but simultaneously on the move and in circulation. ${ }^{84}$ Put differently, banishment does not aim at the repression, but at the institutionalisation of mobility as it deflects and reflects the movements of those deemed 'undesirable'. This more nuanced reading of differential inclusion offered by critical security studies is better equipped to account for the restrictive effects of technologically ever more sophisticated border controls. It's adoption by the CAM presupposes, however, to acknowledge that security does not only work as a force of differentiation, but also as 'a force of abjection excluding risky migrants from trusted travellers' ${ }^{85}$ It is then important to consider the securitisation of migration in the analysis and conceptualisation of border regimes, because it is the complex interplay between the obsession for maximum security brought about by the politics of fear and the economic imperative to facilitate the circulation of commodities and living labour, which fuels the ongoing technologisation of border controls.

Instead of prioritising one of these allegedly conflicting governmental desires over the other, I therefore suggest to conceptualise contemporary border regimes with Foucault's notion of the security dispositif. For the latter captures nicely that freedom is not a value in opposition to or in tension with security concerns. Rather, freedom constitutes a technique of government as it has been reframed as freedom of movement. As such, it provides the raison

\footnotetext{
${ }^{82}$ Didier Bigo, "Detention of Foreigners, States of Exception, and the Social Practices of Control of the Banopticon," in Border-scapes. Hidden Geographies and Politics at Territory's Edge, ed. Prem Kumar Rajaram and Carl Grundy-Warr (Minneapolis: University of Minnesota Press, 2007); ;Jef Huysmans, "A Foucaultian view on spill-over: freedom and security in the EU," Journal of International Relations and Development 7, no. 3 (2004); Julien Jeandesboz, "Les usages de voisin. Genèse, enjeux et modalités des politiques de voisinage de l'Union européenne" (Institut d'Études Politiques de Paris, 2011).: 369-370

${ }^{83}$ Didier Bigo, "Security: A Field Left Fallow," in Foucault on Politics, Security and War, ed. Michael Dillon and Andrew W. Neil (Basingstoke: Palgrave, 2008), 98.

84 "Detention of Foreigners, States of Exception, and the Social Practices of Control of the Banopticon," 31; Jeandesboz, "Les usages de voisin. Genèse, enjeux et modalités des politiques de voisinage de l'Union européenne," 394.

${ }^{85}$ van Munster, Securitizing Immigration. The Politics of Risk in the EU: 66.
} 
d'être of the security dispositif. ${ }^{86}$ Following Foucault, Bigo argues that the reduction of freedom to the promise of global mobility without being stopped ultimately allows for 'policing in the name of freedom', ${ }^{87}$ resulting in ever more pervasive dataveillance. ${ }^{88}$ In Foucault's words, '[...] freedom [of movement] is nothing but the correlative development of apparatuses of security. ${ }^{, 89}$ The security dispositif is not concerned with the protection of the territory of sovereign spaces, but with governing a population in a way that optimises its life potentials and its economic productivity. ${ }^{90}$ Its "problem [...] is no longer that of fixing and demarcating the territory, but of allowing circulations to take place, of controlling them, of sifting the good and the bad, ensuring that things are always in movement [...], but in such a way that the inherent dangers of this circulation are cancelled out. ${ }^{91}$ Foucault indicates that the surveillance of the population becomes a substitute for the protection previously offered by the now dismantled city walls in order to identify individuals within the now freely circulating flows, who might impinge on the economic productivity of the population. ${ }^{92} \mathrm{He}$ specifies that the security dispositif is concerned with anticipating, identifying, minimising potentially harmful elements within the circulating flows through the statistical calculation of possible future behaviours and events. Foucault's stance that the security dispositif 'works on the future ${ }^{93}$ is in conflict with the CAM's premise that migrations temporarily precede the attempts to control and regulate them. Yet, it is precisely the adoption of this endeavour to render uncertain futures knowable and actionable, which explains the appeal of contemporary border regimes to information, identification and surveillance technologies, thereby bringing the third element of the triptych security - freedom of movement - technology into play.

I would therefore like to suggest that it is precisely the misreading of the securitisation of migration as a mere modality for the disenfranchisement and economic exploitation of migrants, which has hindered some of the most prominent advocates of the CAM so far to take the technologisation of border controls and its restrictive effects seriously. This is, however, important, because biometric databases and related border control technologies like

\footnotetext{
${ }^{86}$ Bigo, "Security: A Field Left Fallow," 107.

${ }^{87}$ Didier Bigo and Elspeth Guild, "Introduction: Policing in the Name of Freedom," in Controlling Frontiers: Free Movement into and within Europe, ed. Didier Bigo and Elspeth Guild (Aldershot: Ashgate, 2005$), 1$.

${ }^{88}$ Bigo, "Freedom and speed in enlarged borderzones," 33.

${ }^{89}$ Michel Foucault, Security, Territory, Population (Basingstoke: Palgrave, 2007). 49.

${ }^{90}$ Ibid., 18, 69. In order to highlight the importance of the often neglected economic dimension of the security dispositif, some CSS-scholars argue that 'understanding the deployment of the security dispositif requires an analysis of how circulation functions within capitalism in relation to production and labour.' Claudia Aradau and Tobias Blanke, "Governing circulation: a critique of the biopolitics of security," in Security and Global Governmentality: Globalization, governance and the state, ed. Miguel De Larrinaga and Marc G. Doucet (Oxon and New York: Routledge, 2010), 53.

${ }^{91}$ Foucault, Security, Territory, Population: 65.

${ }^{92}$ Ibid., 18.

${ }^{93}$ Ibid., 20, 61.
} 
the planned entry-exit-system or the EUROSUR project alter the power relations and the encounters between migrants and border control authorities to such an extent that the general assertion of moments of autonomy of migration within any border regime regardless of its legal, practical and technological composition becomes, in fact, a highly dubious claim.

I illustrate my argument with two examples relating to the VIS, because its impact on the possibilities of abjectified migrants to appropriate Schengen visa and subsequently stay in Europe is of particular relevance for the CAM's core thesis. For contrary to the misleading scandalisation of boat migration in the media and by policy makers, most illegalised migrants in Europe do not cross the EU's borders unauthorised, but enter via airports with a valid Schengen visa only to become illegal after it has expired. ${ }^{94}$

The first example relates to the objective of the VIS to prevent the so-called practice of "visa shopping, ${ }^{95}$ This pejorative term refers to the strategy of visa applicants to lodge consecutive applications at consulates of several EU member states, after an initial application has already been turned down. While consulates of Schengen member states have begun to stamp the passports of rejected visa applicants, the latter could previously still lodge further applications at consulates of other member states by obtaining a new passport. ${ }^{96}$ Yet, the VIS efficiently forecloses this possibility for rejected applicants, because consular staff can now check in the biometric database, which also stores the fingerprint templates of rejected applicants for a period of five years, 'if this fingerprint has already applied for a visa' ${ }^{97}$

The second example refers to the objective of the VIS 'to assist in the identification of any person who may not, or may no longer, fulfil the conditions for entry to, stay or residence on the territory of the Member States. ${ }^{98}$ On a practical level, and in less euphemistic terms, the VIS shall facilitate the provision of travel documents for undocumented migrants, who try to hide their identity after being detected by the police, in order to accelerate their deportation.

\footnotetext{
${ }^{94}$ It is by now a well established fact in the migration studies literature that only a very small proportion of the population of illegalised migrants in Europe enter clandestinely, estimates ranging between $5 \%$ and $10 \%$. See for instance: Richard Black et al., "Routes to illegal residence: a case study of immigration detainees in the United Kingdom," Geoforum 37, no. 4 (2006): 560; Michael Collyer, Hein de Haas, and Franck Düvell, "Critical Approaches to Transit Migration," Population, Space and Place 18(2012): 408; Michael Collyer, "Towards Mediterranean Migration Management? Developing Discourse and Practices," in Area Working Paper Nr. 54/2008 (Madrid: Real Instituto Elcano, 2008), 2; Guiseppe Sciortino, "Between Phantoms and Necessary Evils. Some Critical Points in the Study of Irregular Migrations to Western Europe," IMIS-Beiträge, no. 24 (2004): 34.

${ }^{95}$ European Parliament and Council, "Regulation (EC) No 767/2008 of the European Parliament and Council of 9 July 2008 concerning the Visa Information System (VIS) and the exchange of data between Member States on short-stay visas (VIS Regulation)," Official Journal of European Union, no. 218 (2008): 63.

${ }^{96}$ Didier Bigo and Elspeth Guild, "Policing at a Distance: Schengen Visa Policies," in Controlling Frontiers. Free Movement into and within Europe, ed. Didier Bigo and Elspeth Guild (Aldershot: Ashgate, 2005).

${ }^{97}$ Interview with a training supervisor for senior border guards in the Schengen area (January 2012).

${ }^{98}$ European Parliament and the Council, "Regulation (EC) No 767/2008 of the European Parliament and the Council of 9 July 2008 concerning the Visa Information System (VIS) and the exchange of data between Member States on short-stay visas," (Official Journal of the European Union L 218 2008), article 1.
} 
As Dennis Broeders has rightly argued, the VIS will thereby function as a 'system of reidentification' for so-called 'visa-overstayers'. 99 For the purpose of identification a newly generated template of a fingerprint is compared to the up to 70 million templates stored in the VIS. The apprehended person is then reidentified on the basis of the alphanumerical data, which is linked to the matching template.

Both examples highlight that biometric databases like the VIS try to establish what Philippe Bonditti has called traceability i.e. 'the capacity of security agencies to recreate geographical, social and digital trajectories of individuals, goods, capital and data. ${ }^{100}$ In case of the VIS, past trajectories of visa applicants, holders and overstayers can be reconstructed through the collection and storage of the traces they left behind, when they initially applied for a visa. Traceability then works through the creation of 'data doubles'. David Lyon defines a data double as an 'electronic profile compiled out of fragments of personal data of individuals. ${ }^{101}$ This 'digital alter ego, ${ }^{102}$ is then attached by means of biometrics to the body of the person it refers to in order to establish his or her traceability. ${ }^{103}$ In this context, it has been argued that the proliferation of biometric border control technologies is driven by the conception of the "human body [...] as an indisputable anchor to which data can be safely secured. ${ }^{, 104}$ More precisely, biometric technologies transform human bodies into pure information deprived of all corporality in order to create data doubles, which refer back to the individual concerned. The purpose of these data doubles is not to represent the individuals they refer to in an accurate manner, but to enable border control authorities to re-identify and make judgements about them. ${ }^{105}$ Ultimately, biometric databases like the VIS turn migrants' bodies into a means of mobility control, thereby generating a new form of irregularity: the irregularity of the 'data double'. ${ }^{106}$

\footnotetext{
${ }^{99}$ Broeders, "The New Digital Borders of Europe: EU Databases and the Surveillance of Irregular Migrants," 8586.

${ }^{100}$ Philippe Bonditti, "Governing the (im)probable, making the real: antiterrorism and contemporary mutations in the art of governing people" (paper presented at the

Paper prepared for the 'Government and Freedom: Histories and Prospects' seminar series London (12th Jannuary 2010), London, 2010).

${ }^{101}$ David Lyon, Surveillance Studies. An Overview (Cambridge: Polity Press, 2007). 199.

${ }^{102}$ Louise Amoore, "Lines of sight: on the visualization of unknown futures," Citizenship Studies 13, no. 1 (2009): 18.

103 Philippe Bonditti, "L'antiterrorisme aux États-Unis (1946-2007): Une analyse foucaldienne de la transformation de l'exercice de la souveraineté et de l'art de gouverner " (Institut d'Études Politiques de Paris, 2008), 501..

${ }^{104}$ Louise Amoore and Marieke De Goede, "Governance, risk and dataveillance in the war on terror," Crime, Law \& Social Change 43, no. 2 (2005): 163-64.

${ }^{105}$ Kevin D. Haggerty and Richard V. Ericson, "The Surveillant Assemblage " British Journal of Sociology 51, no. 4 (2000): 611-14.

${ }^{106}$ Bigo, "Freedom and speed in enlarged borderzones."
} 
It is precisely this new form of irregularity, which brings to the fore that biometric databases like the VIS intensify the restrictive and exclusionary effects of border controls as they forestall previously successful mobility strategies. It is through the generation of data doubles and the related establishment traceability of people's migration histories that biometric databases like the VIS make it possible to synchronise controls and resulting sanctions. Information on visa applicants, which has been previously scattered over the countless folders of the 3.500 consular posts the EU's member states maintain worldwide, does not only become available, it also accessible within seconds. Since the start of operation of the VIS it just takes consular staff a few seconds to check if an applicant has already been refused a visa and to reject his application. ${ }^{107}$ Through the storage of biometric characteristics it is no longer possible for apprehended migrants to forestall a deportation by destroying their passports and concealing their identity. Rather, visa overstayers are now haunted by their data doubles: If their fingerprints are stored in the VIS, it just takes authorities a few hours to establish their identity and country of origin in order to deport them as soon as possible. Hence, biometric technologies do not only imply a qualitative shift in the efficiency and scope of border controls. More importantly, biometric databases significantly alter the encounters and power relations between migrants and border control authorities. In case of the detection of undocumented migrants, border control authorities no longer depend on the cooperation of migrants to re-identify them, because their data doubles replace their narratives as a source of truth. ${ }^{108}$ Thereby, biometric databases considerably diminish migrants' room for manoeuvre.

To be clear: I am not arguing that biometric rebordering completely deprives migration of its moments of autonomy. Nor do I claim that the appropriation of mobility and rights has become impossible for abjectified migrants within biometric border regimes. ${ }^{109}$ My point is

\footnotetext{
${ }^{107}$ A recent issue of the bulletin of the European Migration Network cites a number of 3.000 persons, who registered multiple applications between January and April 2012 at consulates in one of the six North-African countries, where the VIS has already been in operation since October 2011. Hence, the VIS has assisted in the detection of 3.000 'visa shoppers' within three months in this region alone. Their applications were all rejected. European Migration Network, "EMN Bulletin. A Report from the European Migration Network for the period January to May 2012," EMN Bulletin June 2012(2012).

108 Bigo, "Freedom and speed in enlarged borderzones."; Dennis Broeders, "A European 'Border' Surveillance System under Construction," in Migration and the New Technological Borders of Europe, ed. Huub Dijstelbloem and Albert Meijer (Basingstoke: Palgrave MacMillan, 2011); Irma van der Ploeg and Isolde Sprenkels, "Migration and the machine-readable body: identification and biometrics," in Migration and the new technological borders of Europe, ed. Huub Dijstelbloem and Albert Meijer (Basingstoke: Pallgrave MacMillan, 2011).

${ }^{109}$ To prove the opposite is the research interest guiding my dissertation project, which carries the working title: 'The Visa Information System: Biometric Re-Bordering and the Appropriation of Mobility'. While it is beyond the scope of this article to provide a detailed account of respective practices, it may suffice to indicate some of them: First, abjectified migrants might opt for 'avoiding the "identity routes" of visa and asylum applications when travelling to Europe' Dennis Broeders and Godfried Engbergsen, "The fight against illegal migration: Identification policies and immigrant's counterstrategies," American Behavioral Scientist 50, no. 12 (2007):
} 
rather that the introduction of biometric technologies for border control purposes significantly alters the practical terms and material conditions for the appropriation of mobility. The reason is that biometric technologies render migrants' bodies as a means of control by transforming them into data doubles. Escaping these 'digital alter egos', which determine, if a person is granted a visa or not, and which enable the reconstruction of a person's migration history in order to facilitate her deportation, is no longer simply a matter of burning ones passport. What the fact that asylum seekers have resorted to deliberately cutting or burning their fingerprints in order to prevent an enrolment into EURODAC indicates is that it will afford nothing less than to alter or destroy the minutiae of ones fingerprints. ${ }^{110}$

What the example of biometric rebordering then illustrates is that the warranty of critique, whereupon the CAM does not sufficiently acknowledge the restrictive effects of border controls, increases in context of their technologisation. Biometric rebordering alters the power relations and encounters between migrants and border control authorities to such an extent that the general assertion of moments of autonomy of migration within any border regime regardless of its legal, material and technological composition becomes, in fact, a highly problematic claim. Ultimately, biometric rebordering stipulates a question, namely: What does the assertion of autonomy of migration refer to in the context of border regimes, which transform migrants' bodies through the usage of biometrics into a means of mobility control? In light of this question I conclude that an acknowledgement of the restrictive effects implicated in the technologisation of border controls makes it necessary to rethink not only some of the CAM's central features, but the notion of autonomy itself.

\section{Conclusion: Rethinking the autonomy of migration - rethinking autonomy}

In this article I have attributed the neglect of the technologisation of border controls and its effects on migrants' room for manoeuvre by the existing CAM-literature to a misreading of the securitisation of migration as a mere means for the disenfranchisement and economic exploitation of migrant labour. In order to overcome this economic reductionism I have

1605. Second, the introduction of biometrics does not solve the issue of feeder documents like birth certificates, passports, job contracts etc. upon which the decision to issue a biometric documents like a Schengen visa is based. Muller, Security, Risk and the Biometric State: 19. Third, biometric technologies are introduced in a regime, in which corruption is a structural and widespread phenomenon Alexis Spire, Accueillir ou reconduire: Enquête sur les guichets de l'immigration (Paris: Raisons d'Agir Éditions, 2009). I explore these and other practices of appropriation of Schengen visa in greater detail in my thesis.

${ }_{110}$ Jonathan P. Aus, "Eurodac: A Solution Looking for a Problem?," European Integration Online Papers 10(2006); Benjamin Muller, "(Dis)qualified bodies: securitization, citizenship and identity management'," citizenship Studies 8, no. 3 (2004). 
proposed to draw on Foucault's notion of the security dispositif to conceptualise today's border regimes. As Foucault perceives the security dispositif primarily as a dispositif of circulation, it brings out that security concerns and the promotion of freedom of movement are not in tension, but operate in tandem. It is the interplay between the two, which drives the adoption of a pro-active risk management approach that in turn explains the 'technological imperative' characterising contemporary processes of rebordering.

But the conception of contemporary border regimes as security dispositifs affords to reconsider at least two of the CAM's propositions. First, abjection and banishment have to be conceived as integral moments of governing human mobility through differential inclusion. Adopting the notion of banishment does, however, not imply a return to the paradigm of exclusion. In contrast to exclusion banishment does not aim at the repression of mobility, but at its institutionalisation. The abject are kept in constant rotation by being subjected to the paradoxical freedom of the ban 'to go anywhere except where one wants to go. ${ }^{, 11}$ This is important to note, because it was the paradigm of exclusion the CAM's proponents sought to critique and replace with the notion of differential inclusion in the first place.

Second, the CAM needs a new justification for the analytical-strategical prioritisation of migrants' practices. It is important to retain this feature of the CAM, because it efficiently allows for avoiding a control biased analysis of technologically ever more sophisticated borders regimes. But the CAM's proposition, whereupon migration temporarily precedes the attempts to control and regulate it, becomes untenable in the face of the security dispositif's risk management approach, which strives to render unknown future behaviours knowable in order to make them actionable and governable. What this pro-active risk management approach brings to the fore is that the CAM's assumption of a temporal precedence of migration is underpinned by a reductive reading of power relations. ${ }^{112}$ It therefore becomes requisite to rethink the concept of autonomy in such a way that it offers an alternative, more convincing justification for analytical-strategical prioritisation of migrants' practices.

This brings me to the final, albeit most crucial modification of the CAM: the challenge to rethink the meaning of autonomy in relation to migration. To engage with this challenge is necessary in order to develop the CAM as an approach, which is no longer prone to the accusation of being based on as well as contributing to a romanticisation of migration. It becomes urgent to engage with this challenge, because the warranty of the two allegations,

\footnotetext{
${ }^{111}$ Bigo, "Detention of Foreigners, States of Exception, and the Social Practices of Control of the Banopticon," 26.

112 Anne McNevin, "Ambivalence and Citizenship: theorizing the political claims of irregular migrants," Millennium - Journal of International Studies 41, no. 2 (2013): 193-94.
} 
which fuel this major critique, increases in the context of biometric rebordering. The analysis of the impact of biometric technologies on migrants' possibilities to appropriate mobility and rights allows me to indicate two starting points for the task to rethink autonomy as a concept.

First, it is important to develop of a situated reading of autonomy, which captures, that mobility is always embodied and relational in order to bring out the diversity of migrants' lived experiences and practices. This is a prerequisite for restoring the CAM's capacity to critique the discriminatory effects of biometric borders. The latter imply a simultaneous intensification and concealment of the differentiation of how the border is experienced, depending on people's subject position in terms of class, 'race', gender, country of origin, age and other factors. Donna Haraway's concept of situated knowledge offers a promising starting point for such a re-reading of autonomy. ${ }^{113}$

Second, a rethinking of autonomy needs to answer the question, what the assertion of an autonomy of migration refers to in the face of biometric border regimes, which transform migrants' bodies into a means of mobility control. What the example of biometric rebordering brings to the fore is that governmental technologies for the regulation and control of human mobility have become so pervasive and intrusive that a rethinking of autonomy has to go beyond its Greek etymology of 'self-legislation'. Nor is it credible any more to simply equate autonomy with some form of independency, as in the original formulation of the CAM's core hypothesis in the pioneering work of Yann Moulier Boutang, as cited at the beginning of the article. Autonomy can no longer be thought as an attribute or a quality inherent to migration. Just as the forms and practices of migration are shaped by, and can therefore not be separated from, the conditions, under which they occur, the emergence of moments of autonomy can not be thought independently of the ever more pervasive and intrusive governmental technologies that seek to control and regulate migration. Autonomy has to be rethought as a relational concept. Ranabir Samaddar's proposal to read autonomy as 'the "Other" of governmentality' might offer a promising starting point for this task. ${ }^{114}$

While it is beyond the scope of this article to rethink the autonomy of migration, it should be underscored that this is an endeavour, which is both worthwhile and pertinent. Not only, because the CAM's reading of borders as sites of intensive political struggle over the selective denial and direct appropriation of mobility is well equipped to counter the growing de-politicisation of border controls. Nor only, because the CAM's conception of borders as

\footnotetext{
${ }^{113}$ Donna Haraway, "Situated Knowledges: The Science Question in Feminism and the Privilege of the Partial Perspective," Feminist Studies 14, no. 3 (1988).

${ }^{114}$ Ranabir Samaddar, "The Politics of Autonomy: An Introduction," in The Politics of Autonomy: Indian Experiences, ed. Ranabir Samaddar (New Delhi \& London: Sage Publications, 2005), 10.
} 
conflictive encounters avoids a control biased analysis, which confirms the claims that drive the technologisation of border controls. But also, and most importantly, because the insight of renown migration scholar Stephen Castles, whereupon potential migrants 'do not decide to stay put just because the receiving state says they are not welcome', is still valid in the context of technologically ever more sophisticated border regimes. ${ }^{115}$ In other words, the question how moments of autonomy of migration emerge and persist becomes even more pertinent in the face of attempts to diminish migrants' room for manoeuvre by turning their bodies into a means of mobility control.

\section{Acknowledgements}

Earlier versions of this article were presented at the Millennium conference in London and at the 'New Borderlands or Cosmopolitanism from Below' conference in Oldenburg (Germany). I would like to thank the following people for helpful suggestions and discussions: Claudia Aradau, Jef Huysmans, Bernd Kasparek, Anne McNevin, Martin Noack and Vassilis Tsianos. Thanks also to the two anonymous reviewers and the editors of Millennium, whose comments helped me to refine the arguments presented here.

\section{Author Biography}

Stephan Scheel is a research student in political and international studies at the Open University in Milton Keynes (UK). The working title of his dissertation project is 'The Visa Information System: Biometric Re-Bordering and the Appropriation of Mobility'. He is a member of the 'Network for Critical Border and Migration Regime Research' (kritnet.org).

\footnotetext{
${ }^{115}$ Stephen Castles, "Why migration policies fail," Ethnic and Racial Studies 27, no. 2 (2004): 209.
} 